\title{
Research on Performance Evaluation of Knowledge Management Innovation in Colleges and Universities
}

\author{
Wenjiao Du* \\ International Cooperation \&Exchange Office \\ Yunnan University of Finance and Economics \\ Kunming, China \\ 82734381@qq.com
}

\author{
Hui Yang \\ International Cooperation \&Exchange Office \\ Yunnan University of Finance and Economics \\ Kunming, China \\ 348851618@qq.com
}

\begin{abstract}
In the context of the rapid development of the knowledge economy, knowledge in human resources and science and technology is an important capital to win in the fierce market competition. In universities, the knowledge is the source of life that the universities survive from the world. Currently most scholars who research on knowledge management innovation performance put emphasis on mostly enterprise knowledge management performance, it involves the research of university knowledge management innovation performance rarely. Therefore, the purpose of this paper is exploratory constructing knowledge management innovation performance evaluation model from the related theory of knowledge management in university, and then evaluating the innovation performance of knowledge management in universities.
\end{abstract}

Keywords: knowledge economy, knowledge management, innovation performance evaluation, core competitiveness

\section{INTRODUCTION}

In the era of knowledge economy, colleges and universities play a key role, it is not only the producers of knowledge, the birthplace of knowledge-based talent, the transmitter of knowledge, but also have great influence on restricting the economic growth the same as the forerunner of high and new technology, the technology innovation. Knowledge is the core resource of college management, and it is the core driving force for colleges and universities to gradually enhance their own value creation. The foundation of improving the core competitiveness of colleges and universities is the diverse knowledge you possess, so colleges and universities should put more emphasis on the knowledge management level. Constantly improving the methods of acquisition, sorting, storage, sharing, innovation and application of new knowledge and strengthening university knowledge management innovation ability are that you can better use of knowledge resources in university and enhance the core competitiveness of colleges and universities.

As a management tool and method, knowledge management plays an important role in the innovative research and activities of colleges and universities. Therefore, this paper discusses how to effectively utilize the knowledge in the knowledge economy era, and how to manage knowledge and how to establish a set of relatively scientific knowledge management innovation performance evaluation system, especially the performance evaluation system of university knowledge management innovation, and then it has important practical significance in guiding the innovation activities in colleges and universities and improving the innovation ability and the performance.

\section{THE RELATED THEORY OF KNOWLEDGE MANAGEMENT INNOVATION PERFORMANCE EVALUATION}

\section{A. The concept of knowledge management}

Different scholars have different perspectives on knowledge management research, and there are differences in the definition of knowledge management concepts, and has not formed a consistent view about knowledge management concepts, so the author combined with large amounts of the literature of knowledge management, and then the author is in summary of knowledge management concept, he believed that knowledge management is a kind of integrated management that in order to ensure the best efficiency of limited knowledge the manager control the knowledge itself, the activities of the relevant knowledge, knowledge innovation ability and the person who has knowledge using knowledge management tools and methods in a specific environment and under the condition of limited resources.

\section{B. The components of knowledge management in colleges and universities}

In order to study the constituent elements of knowledge management in university, with the help of Arthur Andersen consulting company the it put forward the famous formula of knowledge management: $\mathrm{KM}=(\mathrm{P}+\mathrm{T}+\mathrm{K}) \mathrm{S}$, the article analyzes the constituent elements of knowledge management in colleges and universities.

Arthur Andersen consulting firm argued that knowledge, knowledge staff and technology, level of knowledge sharing they constitute the structure of knowledge management, as shown in figure 2-1. carrier of knowledge information technology Data, information structure of knowledge management.

*Corresponding author 
Figure 2-1structure of knowledge management

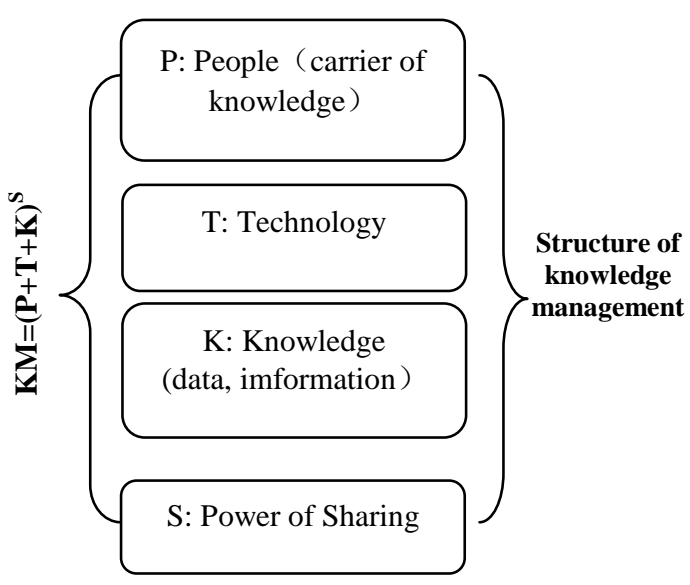

Knowledge management structure contains four parts, namely, knowledge, knowledge people, technology and knowledge sharing, these four parts illustrates components of knowledge management from the different perspective respectively. Knowledge management in colleges and universities also have the four basic elements, but it have a little different. The knowledge management in colleges and universities is to manage the knowledge of university and its relevant factors, including the knowledge personnel management in colleges and universities, information technology management in colleges and universities and knowledge sharing management in colleges and universities.

\section{Knowledge management process in colleges and universities}

Knowledge management in colleges and universities is process that knowledge of colleges and universities is get, created, diffused and shared, innovated and applied. In order to increase the stock of the university internal knowledge, the universities are devoting themselves to get a lot of knowledge and setting up internal knowledge base or internal knowledge map to create knowledge. On this basis, in order to achieve the knowledge sharing level, the colleges and universities disseminate and share knowledge with knowledge base by the teacher's teaching, the students using. Whether the achievements of knowledge management are effective or not, it can be found from the situation of making external connection. For example, whether the results that produced by the university-enterprise cooperation can widely used in the market and get social recognition; Talent Fostered by university would be able to use their own knowledge for the social benefit and so on. Therefore, the paper sets up the knowledge management process based on the essence and connotation of knowledge in university, as shown in figure 2-2.

Thus, the paper wills summary knowledge management in colleges and universities as the four aspects that are knowledge acquisition and creation, knowledge dissemination and sharing, knowledge innovation and knowledge The process of knowledge acquisition and creation is that the teachers and scientific research personnel in colleges and universities obtain new knowledge through external learning, communication or training, and new knowledge will be digested and absorbed and then create distinctive knowledge by way of scientific research, teaching and communication among the team, so as to realize the increase of its utility and the rising of knowledge levels. The process of knowledge sharing's spread is that teachers in college and other people share knowledge with students with by teaching activities and adding to teaching materials, for example, the students understand the tacit knowledge with imperceptibly, so as to realize the transmission of knowledge between teachers and students; Teachers and researchers come true the transmission of tacit knowledge and explicit knowledge among teachers by the team cooperation, academic forum, etc.; Colleges and universities establish effective knowledge base and knowledge map to make teachers and students realize the school knowledge resources sharing. The process of knowledge innovation is that teachers and researchers generate new knowledge by the use of knowledge, especially tacit knowledge, these new knowledge are more efficiency than the original. The process of knowledge application is that the colleges and universities diffuse and "overflow" the knowledge to the outside world through information means, such as network technology, and then realize the marketization of knowledge. They can be came true the industrialization of achievement of knowledge innovation by the way of the cooperation of industry-university-institute, thus they can be converted into marketable products in market or service activities. 
Figure 2- 1 the knowledge management process

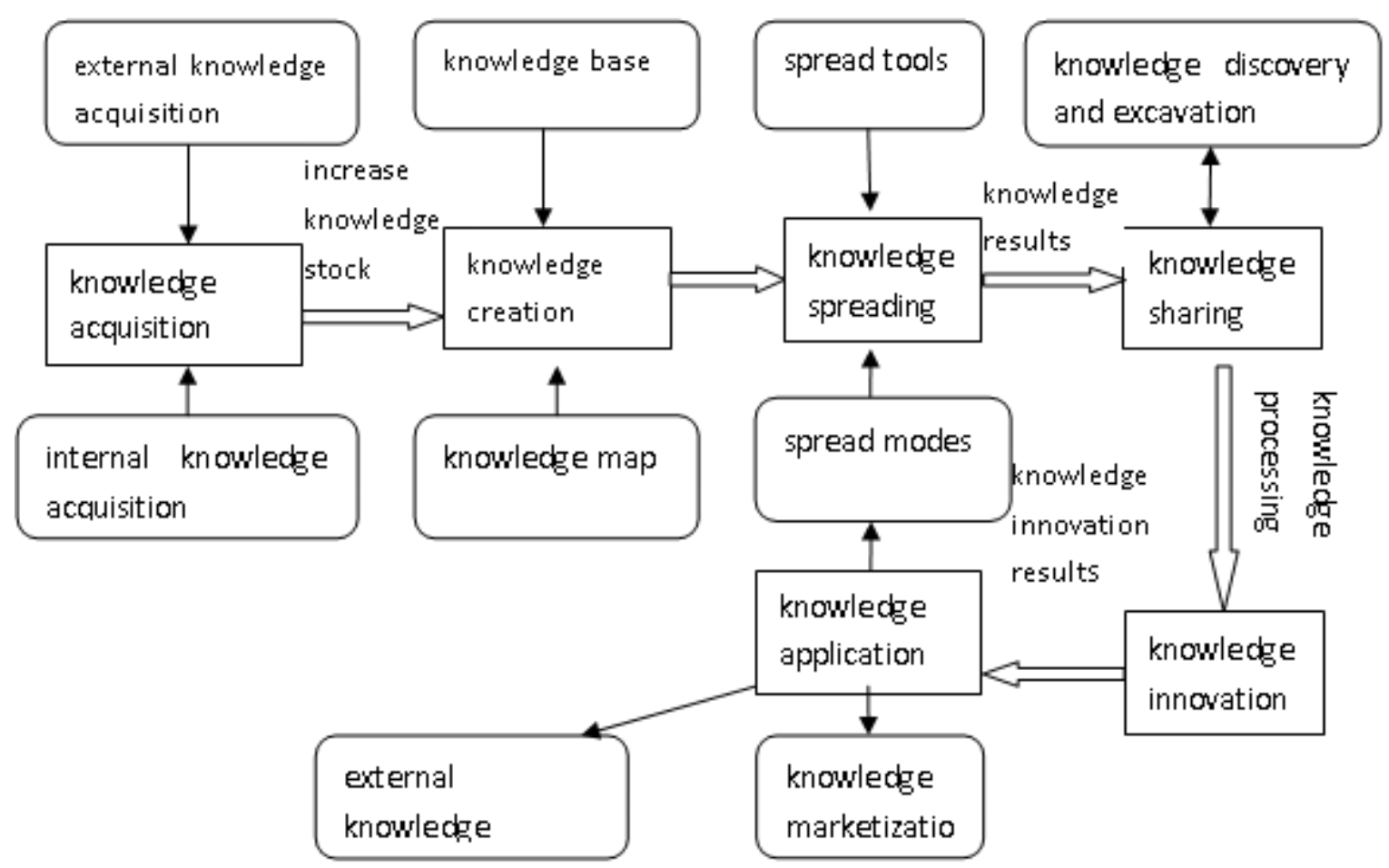

III. THE DEFINITION OF COLLEGES AND UNIVERSITIES' KNOWLEDGE MANAGEMENT INNOVATION PERFORMANCE

\section{A. The definition of innovation performance}

The innovation performance evaluation is the evaluation of achievements of knowledge commercialization. As a result, it gives the significance to research on innovation performance evaluation.Performance is the standard that measured the completed task, including cost, speed, accuracy and integrity, etc. And from the management point, the performance is the results that organization expected to achieve. Innovation is the soul of organization development and the basic way that organizations maintain the core competitiveness and realize the strategic goal, so that the innovation performance is an effective tool to measure organizational innovation effect. Integrating the research of scholars both at home and abroad, the writer knows that the measure of the innovation performance is from the beginning of the innovation, and to the end of the innovation, in the process in need of people, goods, content of input and output, and the evaluation of innovation. Abbreviations and Acronyms

Define abbreviations and acronyms the first time they are used in the text, even after they have been defined in the abstract. Abbreviations such as IEEE, SI, MKS, CGS, sc, dc, and rms do not have to be defined. Do not use abbreviations in the title or heads unless they are unavoidable.

\section{B. The necessity of colleges and universities' knowledge management innovation performance analysis}

The performance evaluation of knowledge management in colleges and universities is to evaluate the performance of knowledge and knowledge management in all aspects of the university to study the level reached by different aspects of university knowledge management. If the colleges and universities want to improve its comprehensive strength, they should firstly be clear its knowledge management level, only knowing their own strength can take appropriate measures, so as to improve the knowledge level and the comprehensive competitiveness of the university. Therefore, studying the necessity of colleges and universities' knowledge management innovation performance analysis is very important, so this article mainly analyzes its necessity from the following aspects:

1. Contributing to improve the ability knowledge management innovation in colleges and universities. Life and soul of knowledge economy lies in innovation, only innovation, can use the knowledge to a greater extent and play a higher efficiency about knowledge. Therefore, the ultimate goal of knowledge management is innovation. University knowledge management innovation is not be done at a time, is the constant 
innovation, which can truly achieve knowledge management innovation. Innovation performance evaluation of knowledge management can promote the knowledge management achieve a higher direction, thus promote knowledge management innovation ability in advance again and again.

2. Contributing to improve the comprehensive competitiveness of colleges and universities. Carrying out new measures for knowledge management innovation in colleges and universities is an important method and means to improve the comprehensive competitiveness of colleges and universities Therefore, the performance evaluation becomes the bridge between the universities' knowledge management innovation project and the comprehensive competitiveness. It should timely evaluate the knowledge management innovation project performance in colleges and universities, and then discard the dross and select the essence, promote the comprehensive competitiveness of the university itself in constant innovation. 4 Performance evaluation and function of knowledge management innovation in university

\section{UNIVERSITY KNOWLEDGE MANAGEMENT INNOVATION PERFORMANCE EVALUATION AND FUNCTION}

\section{A. Performance evaluation of knowledge management innovation in university}

The purpose of implementing knowledge management innovation in colleges and universities is to hope to be able to obtain the biggest benefit from the knowledge management and promote the maximization of knowledge utilization efficiency of colleges and universities. But the bad or good when implemented needs an evaluation system to identify. The advantages and disadvantages of university knowledge management innovation level and the existing problem are not obvious, which requires knowledge management innovation level in colleges and universities to make a feedback of the evaluation, and found problems of knowledge management in colleges and universities through the evaluation results, then adjust the effective parameters reasonably in order to make the management system more practical, so that it can promote the progress of knowledge management activities.

\section{B. The function of knowledge management innovation in university}

Performance evaluation system is a community of joint operation constituted by multiple subsystems, through the indicators of decomposition and scientific measurements which it is not only to obtain data simply, but also further analysis and get the efficiency of implementation and problems of research object, which provides the guidance for action and decisionmaking basis for policymakers.

1. Providing standards for the effective implementation of knowledge management in colleges and universities

Knowledge management is expanding around the "knowledge", which this knowledge can be divided into explicit knowledge and tacit knowledge. In the process of knowledge innovation in colleges and universities, tacit knowledge plays an important role. So building a set of the completed knowledge management innovation performance evaluation system can make the university's tacit knowledge materialization, thus is conducive to the implementation of knowledge management innovation in colleges and universities.

2. Providing scientific basis for knowledge management innovation decision in colleges and universities

Objectively evaluating the innovation performance of knowledge management and based on the assessment of the data and the evaluation index in a timely manner quickly found the problem from the acquisition of knowledge, identification of knowledge, knowledge sharing and knowledge innovation, so as to provide important reference information for colleges and universities in the late planning and strategy.

3. Promoting the value maximization knowledge management in colleges and universities.

Through knowledge management performance evaluation can influence on the personal to promote their own goal towards organizational goal, thus it can make action consistent with organizational goals, so it can enhance knowledge management personnel's sense and belonging.

\section{CONSTRUCTING THE INDEX SYSTEM AND MODEL OF KNOWLEDGE MANAGEMENT INNOVATION PERFORMANCE EVALUATION IN COLLEGES AND UNIVERSITIES}

\section{A. The design principles of the index system of knowledge management innovation performance evaluation in colleges and universities}

In knowledge management innovation performance evaluation system in colleges and universities, there are involving many factors for performance evaluation, and the structure is not simple. Therefore, if you want to reflection of knowledge management of the project's performance level with truly and accurately, you must design the performance evaluation index system from several aspects and multiple Angle. So, the paper argues that designing the knowledge management innovation project performance evaluation system should follow the following aspects:

1. The selected indicators must follow the principle of objective and truth

The project of knowledge management innovation in university is regarded as evaluation objects, so in the process of the evaluation, the selected evaluation subject should choose some the indicators with practical and conforms for the project, the knowledge management should base us on reality in everything we do. The university knowledge management innovation project performance evaluation must be based on objective facts, namely the design of evaluation indexes should reflect the situation of the management innovation of knowledge actually, and then can avoid some subjective factors that affect the accuracy of indicators. Only evaluating with objective and truth, can real reaction the level of university knowledge management innovation.

2. The selected indicators must have the operability and comparability 
The establishment of the index system of university knowledge management innovation performance will in need of the evaluation index that are easy to collect and quantification. And the comparable indicators mainly reflect two aspects. One is that the evaluation index should be comparable in a different time or space scope. The indicators do not change significantly over a longer period, or the indicators have a little difference between different knowledge management innovation projects, all those should not be included in the evaluation index system; the other one is that when the comparison occurred between different knowledge management innovation project, the evaluation index system should be comparable in terms of the degree and the scope.

\section{B. The design basis of the index system of knowledge management innovation performance evaluation in colleges and universities}

The design basis of knowledge management innovation performance evaluation index system in university must be the followed subjective and objective criteria in the design process of knowledge management innovation performance evaluation indexes, including the purpose of performance evaluation, the objects performance evaluation, and the methods and tools of performance evaluation, et

The methods and tools of performance evaluation are the methods and tools that are used for gathering the data and information of performance evaluation. And it is necessary that the data and information of the performance evaluation can be collected with timely, accurately and adequately, and according to the index information effectively, we can adjust the performance evaluation index system, all those thing we requires full consideration evaluation methods and tools we used, and different methods and tools is in need of indicators that have different structures and properties.

\section{CONCLUSION}

The evaluation of knowledge management innovation in colleges and universities is based on the knowledge management innovation and find out the main factors influencing the performance, so as to realize the reasonable configuration of knowledge resources in colleges and universities and maximize the value of knowledge. The first problem of implementing knowledge management innovation is built the performance evaluation index system, because scientific and reasonable index system can assure of the scientific and reasonable evaluation result. The article makes the exploratory research around the knowledge management innovation performance evaluation, and draws lessons from the related theory of knowledge management and related research results, so can get some conclusions: This paper defines the connotation of knowledge management and knowledge management innovation in colleges and universities and analyzes the performance evaluation of knowledge management innovation in university and its role.

\section{REFERENCES}

[1] Xiang Zhang. Research on Information System Integration Project Management in Colleges and Universities [D]. Southwest Jiaotong University, 2011.

[2] Yajun Guo.(2011). Research of knowledge management pattern in colleges and universities for teaching innovation. The modern intelligence,(4):.11-14.

[3] Xi Huang.(2013). Based on the analysis of the problems in the implementation of knowledge management strategy research. Chinese management informationization,(11):103-105.

[4] Meihong Tong. Research on performance analysis based on knowledge management in colleges and universities[D]. Taiyuan University of Technology, 2013

[5] Wujin Xiong.(2014). Introduction to the library knowledge managemen innovations in university. Neijiang technology, (3):43.

[6] Mengya Wang.(2012). Knowledge management: the new perspective of management innovation in colleges and universities. Journal of Xuchang university,(6):146-148

[7] Dongxue Wang.(2011). Researching on knowledge managemen performance evaluation with Production-study-research cooperative innovation. Master thesis of Harbin engineering university.

[8] Xiangdong Zhan.(2011). The research of knowledge management in university based on knowledge value chain. Technology and innovation management,(9):451-454

[9] Hang Zhao.(2011). The management innovation of teaching team construction in colleges and universities based on knowledge management. Journal of Langfang Teachers University(Natural Science Edition),(6):133-136.

[10] Ningning Yan. Research on Teaching Performance Evaluation of University Teachers[D]. Wuhan University of Technology, 2013 